\title{
LIFETIME ESTIMATIONS OF THE OPERATING MECHANISM OF KAPLAN TURBINE RUNNER BLADES
}

\author{
Ana-Maria Budai, Viorel Constantin Campian, Doina Frunzaverde, Calin Miclosina, Damaschin Pepa
}

Original scientific paper

The paper contains a complex analysis regarding the steps that must be followed in order to estimate the lifetime of the operating mechanism of Kaplan turbine runner blades. The work is structured in 3 parts, every one corresponding to a step that is followed: determination of the real load on operating mechanism, results of operating tests made to determine stress amplitude on operating mechanism lever pin and real fatigue cycles, numerical simulation of stresses on lever pin, lifetime estimations. The work reveals: the area where the maximum stress is located, the value of stress amplitude for lever pin, the location of maximum elongation and the importance of knowing the real number of fatigue cycles in lifetime estimations process.

Keywords: fatigue; Kaplan turbine; lifetime; operating mechanism; runner blade

Procjene trajanja radnog mehanizma lopatica rotora Kaplan turbine

Izvorni znanstveni članak

U radu se daje složena analiza postupaka koji se moraju slijediti kako bi se procijenio vijek trajanja radnog mehanizma lopatica rotora Kaplan turbine. Rad je podijeljen u tri dijela, a svaki odgovara koraku koji se slijedi: određivanje stvarnog opterećenja radnog mehanizma, rezultati operativnih ispitivanja u svrhu određivanja amplitude naprezanja na osovinici poluge radnog mehanizma i stvarnih ciklusa zamora materijala, numeričke simulacije naprezanja na osovinici poluge, procjene trajanja. Rad otkriva: područje lociranja maksimalnog naprezanja, vrijednost amplitude naprezanja na osovinici poluge, određivanje maksimalnog izduljenja i važnost znanja stvarnog broja ciklusa do zamora u procjeni vijeka trajanja.

Ključne riječi: Kaplan turbina; lopatica rotora; radni mehanizam; radni vijek; zamor

\section{Introduction}

In the last period, the strength calculus has become more and more complex, this being a normal response to real challenges met in engineering practice. In the past century, to design of any type of structure assumed a strength calculus that provides good results for a static exploitation condition.

For parts in contact different parameters influence the stress distribution in the contact area, in terms of kinematic ones: the loading value, contact surface curvature, contact friction, residual stresses and elastohydro-dynamic lubrication [1].

The situation is completely changed in the case of dynamic condition, when structure operates in variable load conditions. In this case, the classic strength calculus does not provide satisfactory results so a lot of researchers start experimental tests to find the reason of lifetime shortening $[2,3]$.

Lately, the attention has often been directed to hydraulic structures and to their possible optimization [4, 5], the renewable energy representing the alternative for the future instead of the classic ones.

Over the time, the real situation has shown that the Kaplan turbines are one of the perfect candidates to fatigue breaks appearance [6, 7]. One of the Kaplan turbines structure, most stressed, is the runner blade [8] and its operating mechanism, all its components [9], especially the lever pin.

In this paper a possible method used to estimate fatigue lifetime of operating mechanism lever pin is presented. It is an experimentally analytic method based on measurement of real cycle solicitation of lever pin [10].

The method, an experimental - analytic one, can be used for evaluation of fatigue lifetime of machine already in operation, being useful both to re-evaluate the exploitation condition and, in the same time to rehabilitate various components [11].

The approach also requires a Wöhler diagram for the lever material and a numerical simulation of stresses that appear in moving lever pin [12]

All these aspects will be treated in this paper, starting from real entry data obtained by measurement or calculus from an operating Kaplan turbine. The results of fatigue lifetime calculus [13] became very important in fatigue design process [14].

\section{The real fatigue cycles and experimental tests on Kaplan turbine}

The experimental tests were performed using recordings performed in power plant, every 10 seconds, the controller being set to frequencies insensitivity of \pm 40 $\mathrm{mHz}$.

The measurements were made for 6 hydropower plant groups. For processing and subsequent analysis MSExcel macros programmed in Visual Basic were used.

Table 1 Fatigue cycles

\begin{tabular}{|c|c|c|c|c|}
\hline $\begin{array}{c}\text { Power } \\
\text { deviation }\end{array}$ & \multicolumn{2}{|c|}{ Year " $n "$} & \multicolumn{2}{|c|}{ Year " $n+1 "$} \\
\hline \multirow{4}{*}{$\begin{array}{l}\text { higher } \\
\text { than } \\
\pm 1 \mathrm{MW}\end{array}$} & \multirow{2}{*}{$\begin{array}{l}\text { Average / } \\
\text { hour }\end{array}$} & $\begin{array}{l}\text { Cycles } \\
\text { number }\end{array}$ & \multirow{2}{*}{$\begin{array}{c}\text { Average / } \\
\text { hour }\end{array}$} & $\begin{array}{l}\text { Cycles } \\
\text { number }\end{array}$ \\
\hline & & 9,53 & & 7,77 \\
\hline & \multicolumn{4}{|c|}{ Cycles average / 2 years } \\
\hline & \multicolumn{4}{|c|}{8,65} \\
\hline \multirow{4}{*}{$\begin{array}{c}\text { higher } \\
\text { than } \\
\pm 0,5 \mathrm{MW}\end{array}$} & \multirow{2}{*}{$\begin{array}{c}\text { Average / } \\
\text { hour }\end{array}$} & $\begin{array}{l}\text { Cycles } \\
\text { number }\end{array}$ & \multirow{2}{*}{$\begin{array}{c}\text { Average / } \\
\text { hour }\end{array}$} & $\begin{array}{l}\text { Cycles } \\
\text { number }\end{array}$ \\
\hline & & 22,8 & & 17,41 \\
\hline & \multicolumn{4}{|c|}{ Cycles average / 2 years } \\
\hline & \multicolumn{4}{|c|}{20,105} \\
\hline
\end{tabular}


The processing data, obtained for a power deviation higher than $\pm 1 \mathrm{MW}$ (interval of $2 \mathrm{MW}$ ) respectively for a power deviation higher than $\pm 0,5 \mathrm{MW}$ (interval of $1 \mathrm{MW}$ ) are given in Tab. 1 .

\section{Numerical simulation of stresses on lever pin}

The numerical simulation of stresses on lever pin was made using the finite element analysis module SolidWorks Simulation software.

The geometrical model of runner-lever assembly was imported from Autodesk Inventor software, using the standard format IGES (Fig. 1).
Before the numerical simulation, it is necessary to perform an analysis to determine the afferent entry data, analysis that was performed with the SolidWorks Motionmodule.

From measurements made in frequency adjustment regime, for calculus and analyses a dynamic load regime for lever pin was selected, having o force contained in the range 1716,528 kN - 2839,531 kN (Tab. 2 and Fig. 2). The operating power was approximately $192 \mathrm{MW}$.

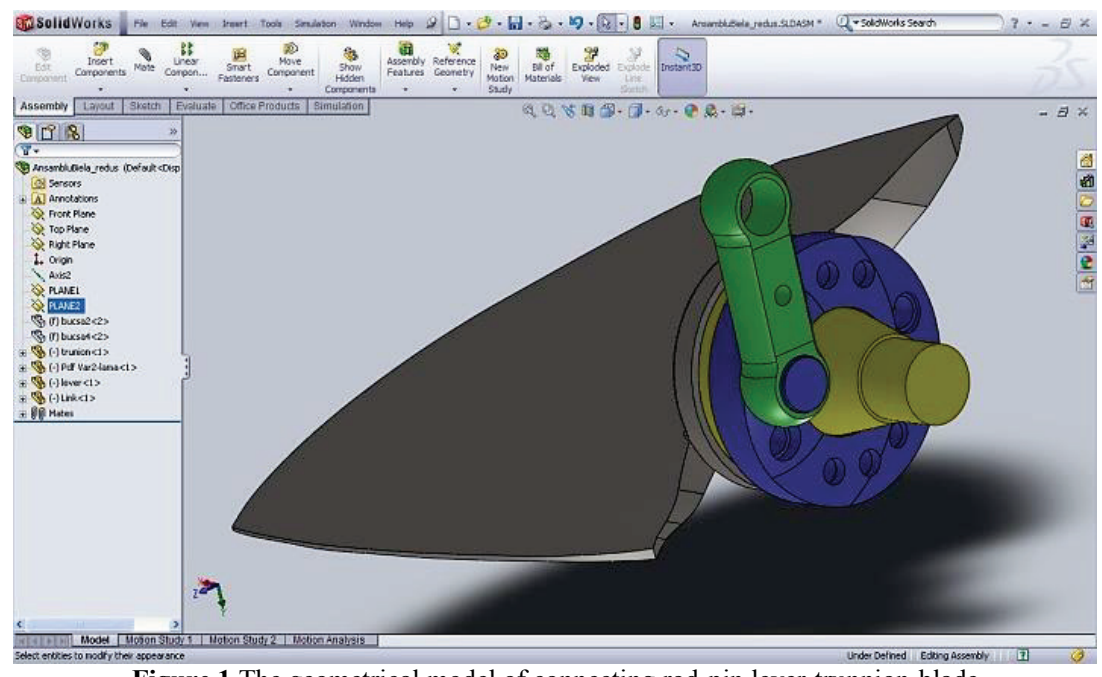

Figure 1 The geometrical model of connecting rod-pin lever-trunnion-blade

Table 2 Working regime parameters

\begin{tabular}{|c|c|c|c|c|c|c|c|}
\hline Time & $\begin{array}{c}\text { Pactive } \\
/ \mathrm{MW}\end{array}$ & $\begin{array}{c}\text { RU_OpenPR } \\
/ \mathrm{MPa}\end{array}$ & $\begin{array}{c}\text { RU_Close PR } \\
/ \mathrm{MPa}\end{array}$ & $\begin{array}{c}\text { RU_Diferen-ce } \\
/ \mathrm{MPa}\end{array}$ & $\begin{array}{c}\text { Head_Water } \\
/ \mathrm{m}\end{array}$ & $\begin{array}{c}\text { RU_Ope-ning } \\
/ \%\end{array}$ & $\begin{array}{c}\text { WG_Op-ening } \\
/ \%\end{array}$ \\
\hline $0: 00: 00$ & 192,4190 & 1,512153 & 0,097222 & 1,414930 & 26,77 & 82,23 & 90,12 \\
\hline $0: 00: 01$ & 191,6233 & 1,687500 & 0,081597 & 1,605902 & 26,77 & 82,23 & 90,12 \\
\hline $0: 00: 01$ & 191,7679 & 2,407986 & 0,098958 & 2,309027 & 26,76 & 82,27 & 90,12 \\
\hline $0: 00: 02$ & 192,2020 & 2,282986 & 0,105902 & 2,177083 & 26,76 & 82,27 & 90,12 \\
\hline $0: 00: 03$ & 192,1296 & 2,116319 & 0,107638 & 2,008680 & 26,76 & 82,60 & 90,27 \\
\hline $0: 00: 05$ & 192,4190 & 1,824653 & 0,102430 & 1,722222 & 26,76 & 82,60 & 90,27 \\
\hline $0: 00: 07$ & 192,5637 & 1,614583 & 0,102430 & 1,512152 & 26,75 & 82,43 & 90,24 \\
\hline $0: 00: 09$ & 192,4190 & 1,491319 & 0,095486 & 1,395832 & 26,75 & 82,35 & 90,19 \\
\hline
\end{tabular}

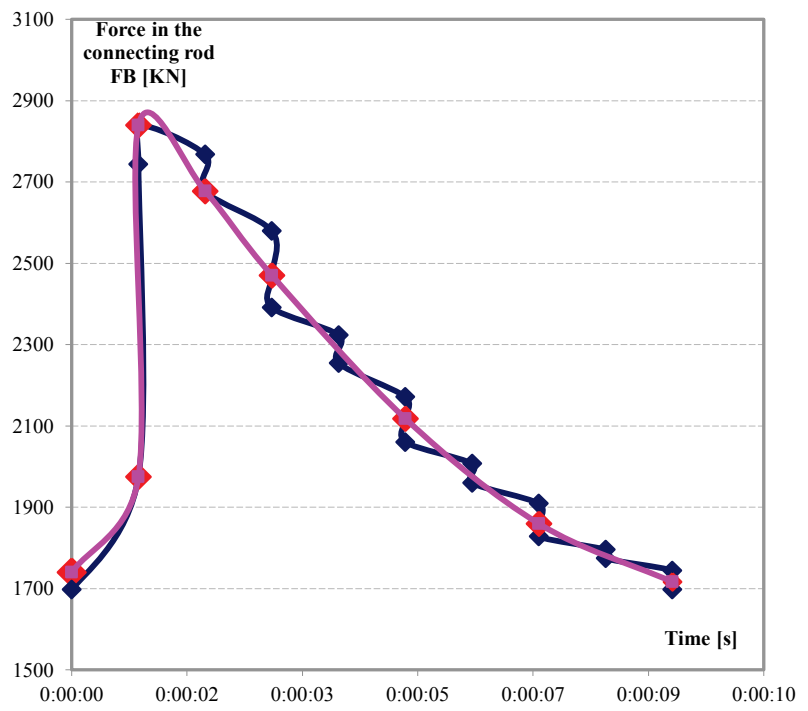

Figure 2 Force in the connecting rod, depending of time
From Tab. 1 the entry data for dynamical calculus were selected, which are:

- the assembly study time was 8 seconds;

- the translation stroke of rod along the machine axis (Tab. 2 and Fig. 3);

- $\quad$ the rotation angle of runner blade (Tab. 2 and Fig. 4);

- the force in connecting rod (Tab. 3 and Fig. 2).

After SolidWorks Motion analysis the following results were obtained:

- $\quad$ the resulting force $\mathrm{N}$ on pin depending on time (s);

- the force components after X, Y, Z, depending on time (s);

- $\quad$ the resulting moment in pin $(\mathrm{N} \cdot \mathrm{mm})$;

- the stroke rod on the vertical direction along the machine axis ( $\mathrm{mm})$. 
Table 3 Force in the connecting rod

\begin{tabular}{|c|c|c|c|}
\hline Time / s & $\begin{array}{c}\text { Force in the } \\
\text { connecting rod } \\
(\mathrm{FB}) / \mathrm{kN}\end{array}$ & $\begin{array}{c}\text { Stroke of the } \\
\text { connecting rod / } \\
\mathrm{mm}\end{array}$ & $\begin{array}{c}\text { Rotation } \\
\text { angle } \varphi /{ }^{\circ}\end{array}$ \\
\hline $0: 00: 00$ & 1740,013522 & 246,69 & 12,81658 \\
\hline $0: 00: 01$ & 1974,861662 & 246,69 & 12,81658 \\
\hline $0: 00: 01$ & 2839,530686 & 246,81 & 12,82767 \\
\hline $0: 00: 02$ & 2677,271751 & 246,81 & 12,82767 \\
\hline $0: 00: 03$ & 2470,177754 & 247,80 & 12,91912 \\
\hline $0: 00: 05$ & 2117,905912 & 247,80 & 12,91912 \\
\hline $0: 00: 07$ & 1859,571974 & 247,29 & 12,87201 \\
\hline $0: 00: 09$ & 1716,527860 & 247,05 & 12,84984 \\
\hline
\end{tabular}

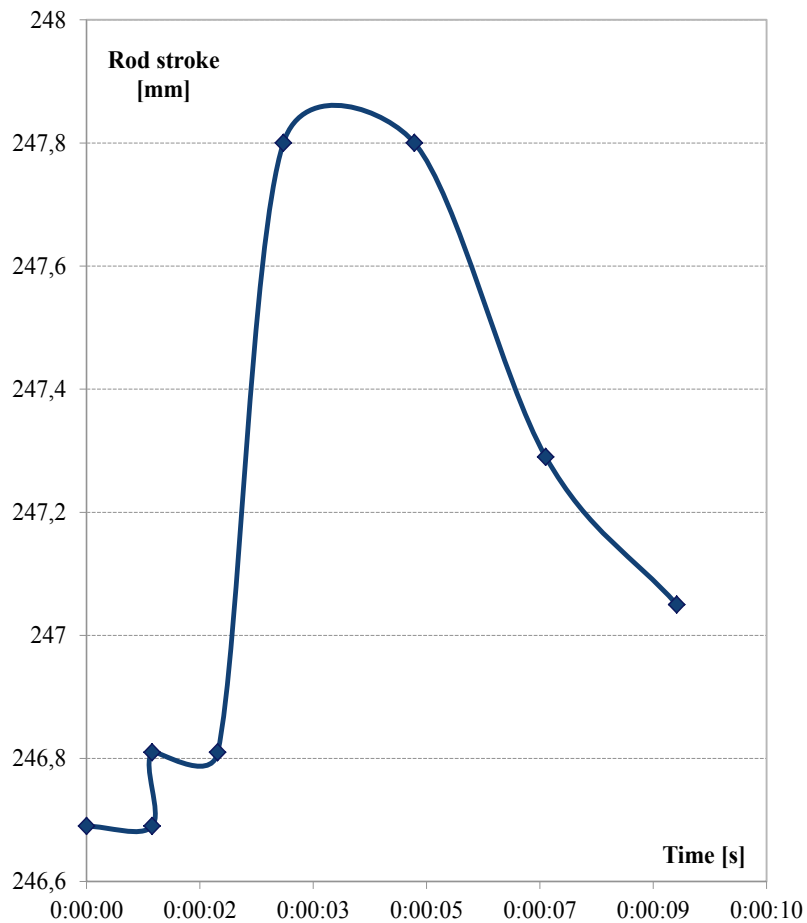

Figure 3 The connecting rod stroke depending on time (mm)

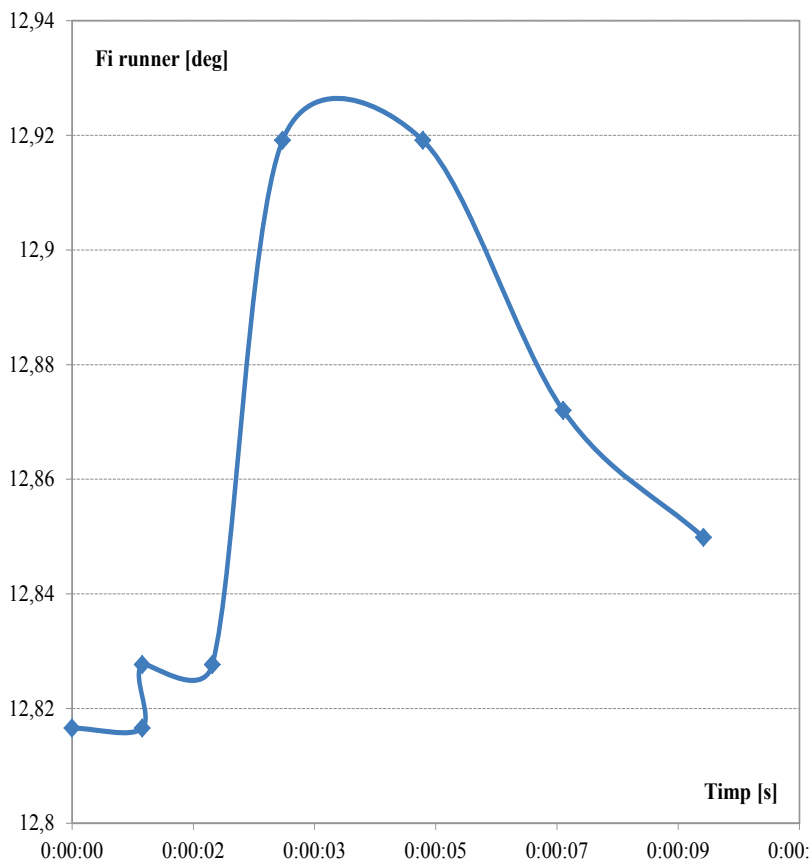

Figure 4 The rotation angle of blade $\varphi\left(^{\circ}\right)$

In order to verify the simulation, the vertical displacement (OY) for rod, according to the machine axis, was calculated. The vertical displacement must be equal to the calculated one for the imposed angle of runner blade.

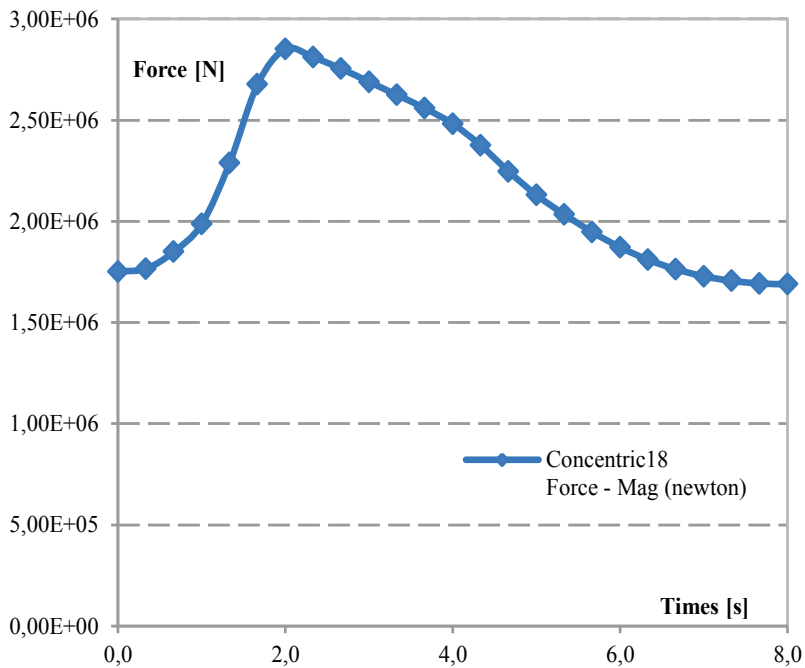

Figure 5 The resulting force $(\mathrm{N})$ in pin, depending on time (s)
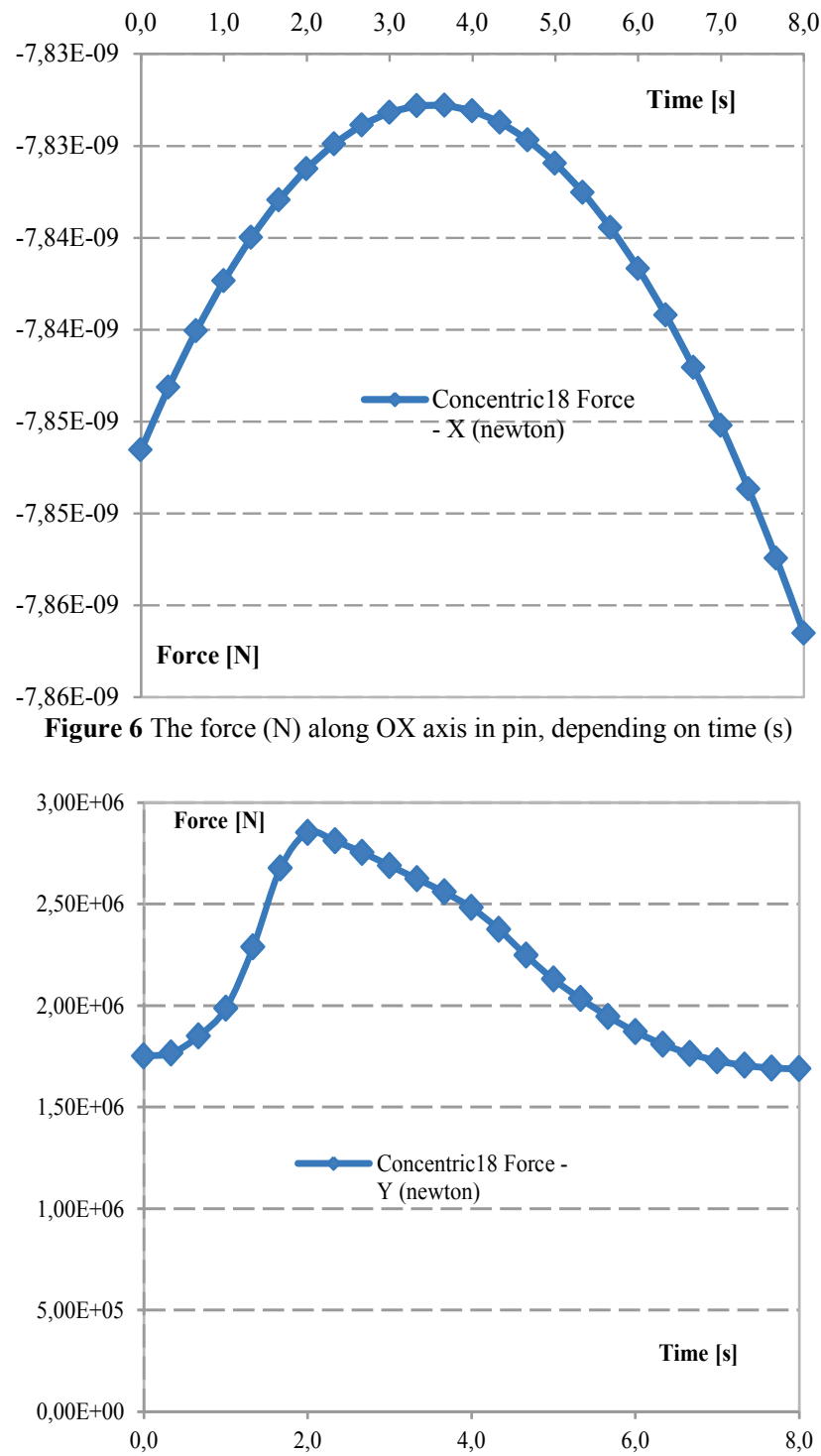

Figure 7 The force $(\mathrm{N})$ along OY axis in pin, depending on time (s) 
The SolidWorks Simulation analysis assumed the hypothesis of the resulting force for the most unfavourable motion, namely for its highest value. In the presented case, this corresponds to maximum value of $2851 \mathrm{kN}$.

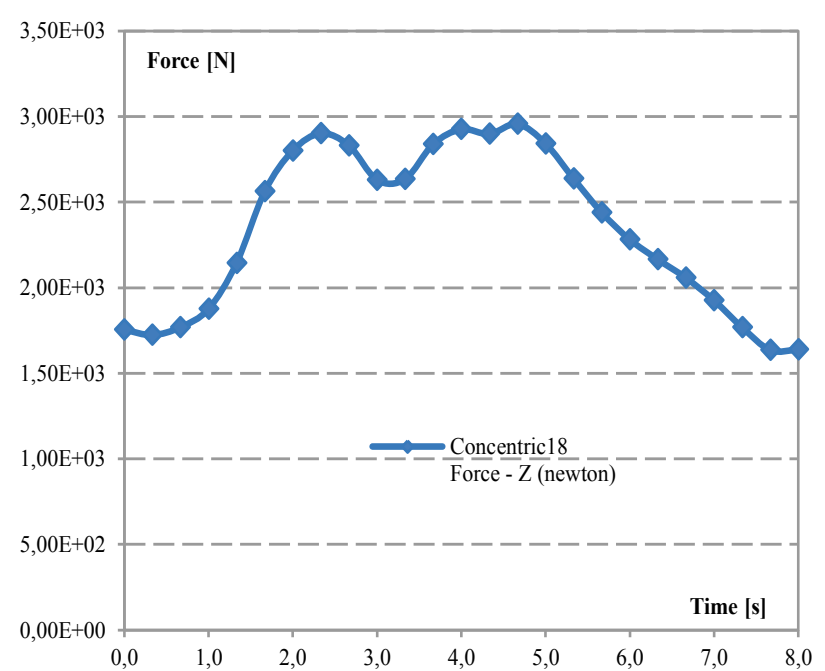

Figure 8 The force $(\mathrm{N})$ along $\mathrm{OZ}$ axis in pin, depending on time (s)

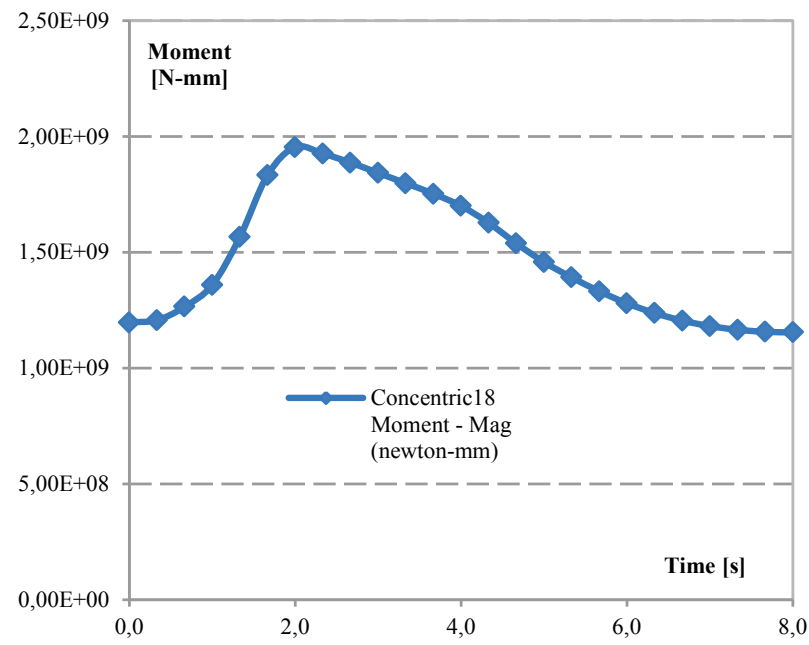

Figure 9 The resultant moment in pin $(\mathrm{N} \cdot \mathrm{mm})$, depending on time $(\mathrm{s})$

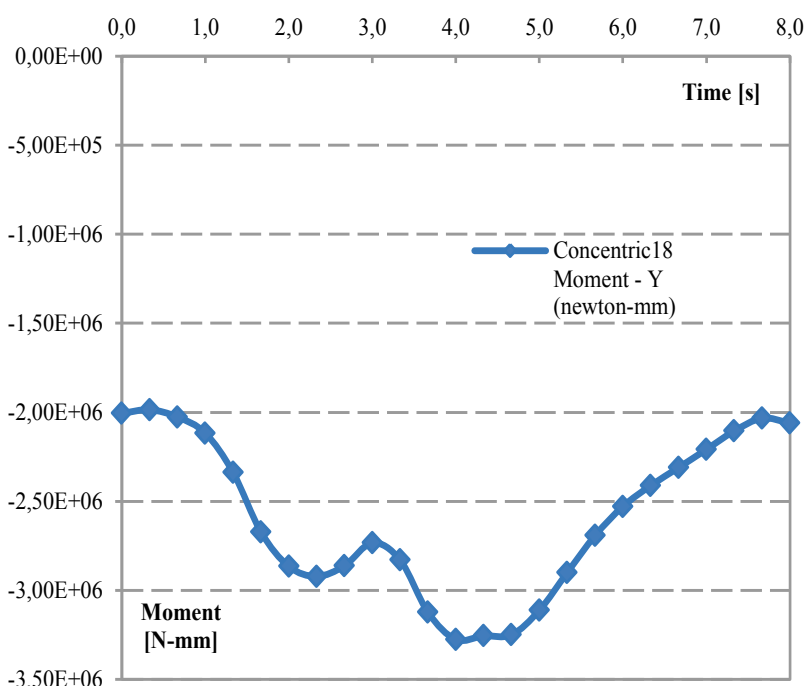

Figure 10 The moment $(\mathrm{N} \cdot \mathrm{mm})$ along $\mathrm{OY}$ axis in pin, depending on time $(\mathrm{s})$
After exporting the loading from SolidWorks Motion, the lever was imported in Simulation module, where it is completed with limit condition (Fig. 13).

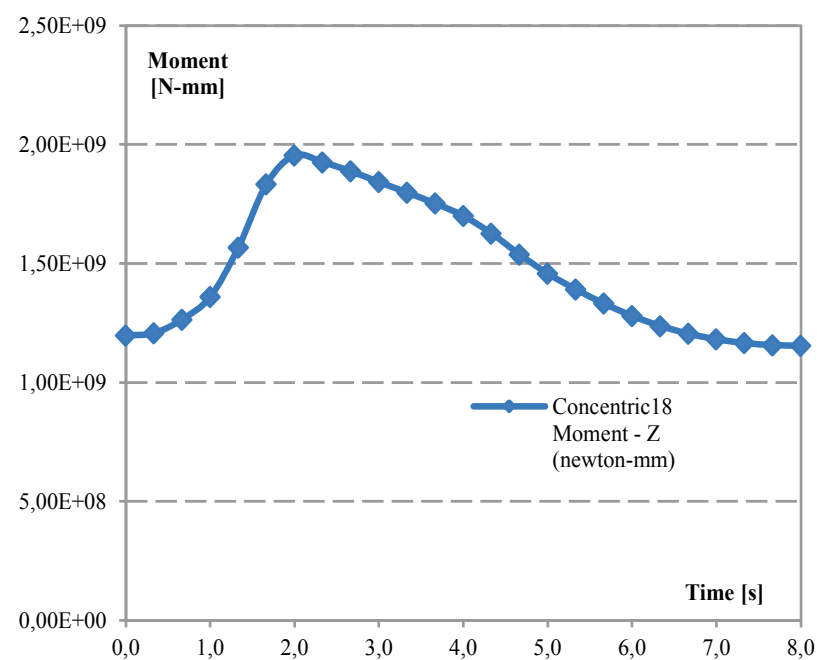

Figure 11 The moment $(\mathrm{N} \cdot \mathrm{mm})$ along $\mathrm{OZ}$ axis in pin, depending on time (s)

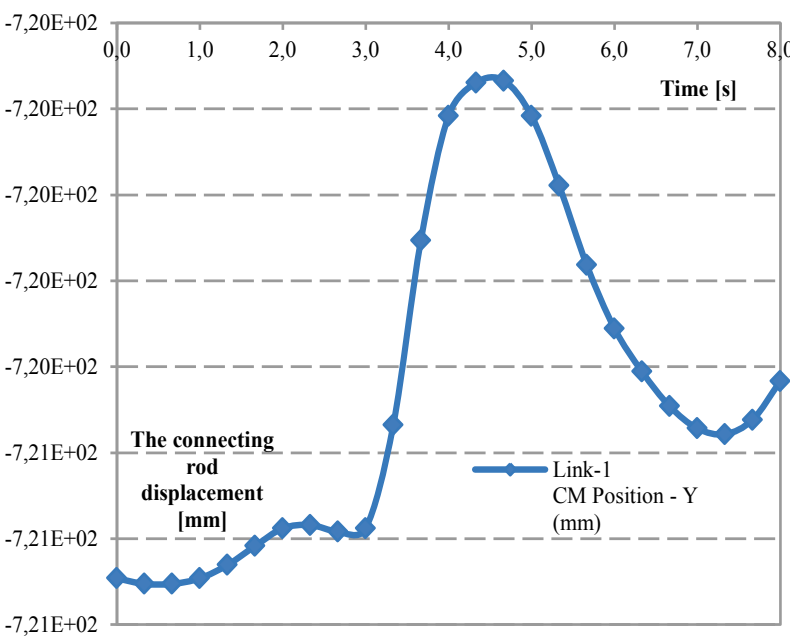

Figure 12 The connecting rod displacement $(\mathrm{mm})$, depending on time (s)

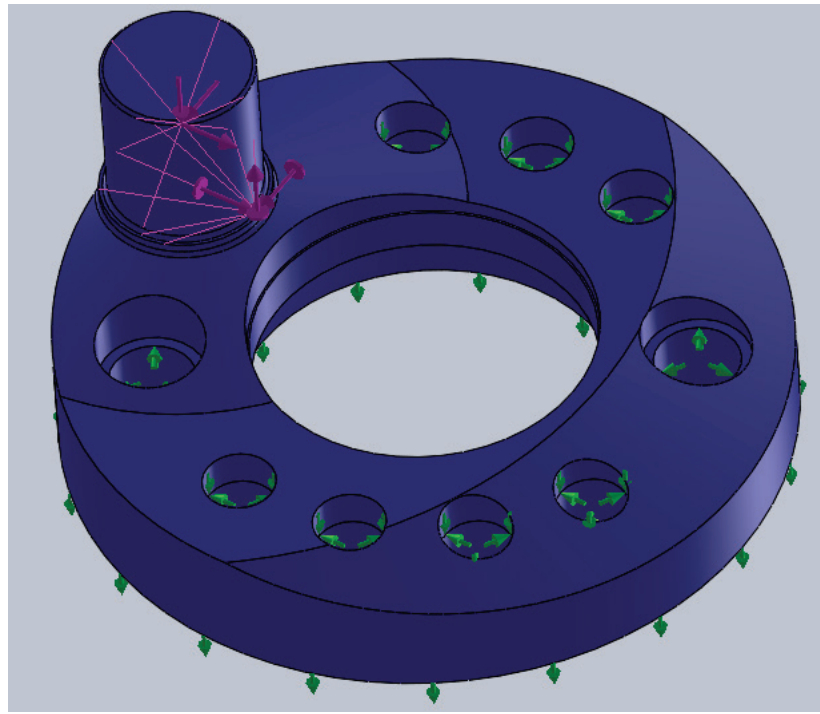

Figure 13 The lever pin load 
After finite elements analysis, with SolidWorks Simulation, the following stresses and deformation distribution for lever pin were obtained:

- the equivalent von Mises stresses distribution (MPa) (Fig. 14)

- the deformations distribution (mm) (Fig. 15)

- the safety factor distribution (Fig. 16).

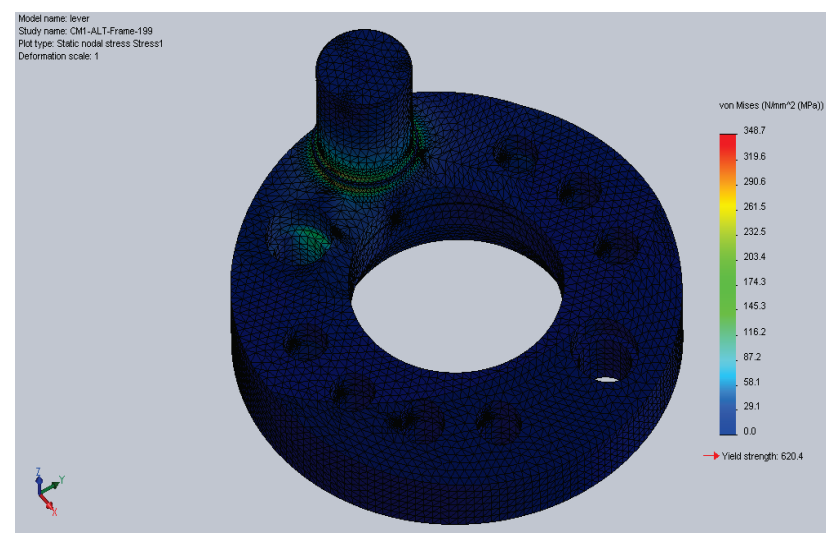

Figure 14 The equivalent von Mises stresses distribution (MPa)

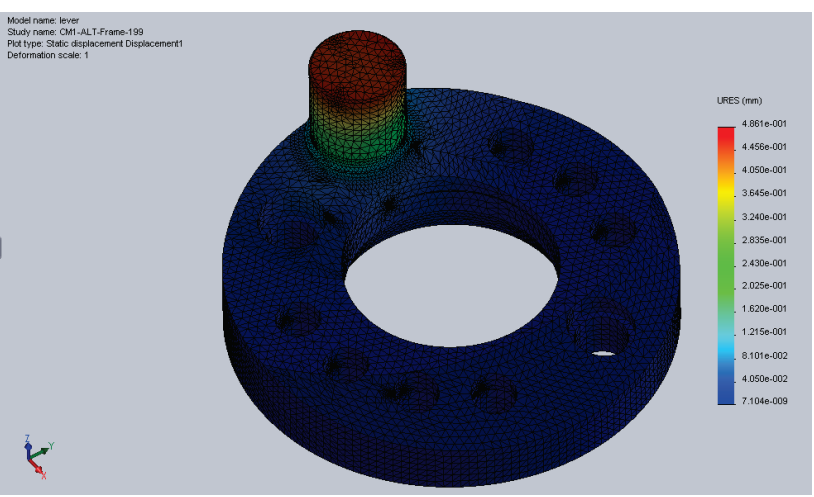

Figure 15 The deformations distribution (mm)

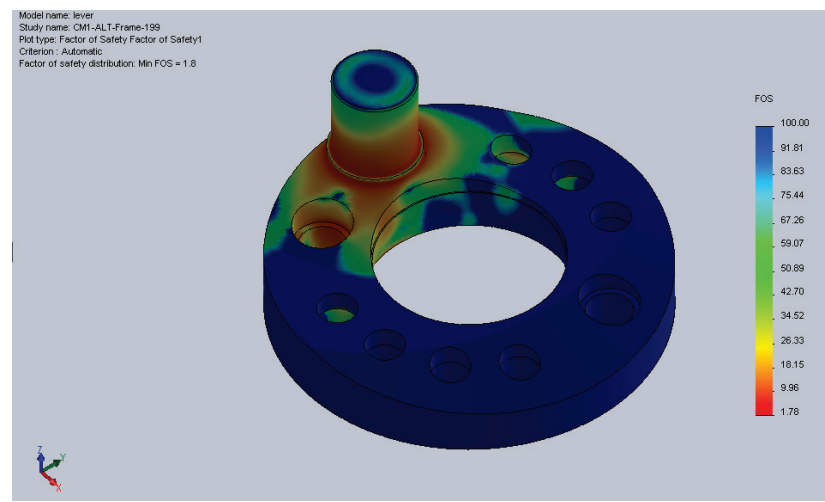

Figure 16 The safety factor distribution

\section{Estimation of lifetime}

In the absence of a fatigue curve corresponding to lever material, in order to estimate the lever pin lifetime the fatigue curve from Fig. 17 was used. This curve corresponds to a material with mechanical proprieties almost similar to the lever material [15].

The lifetime results from stress amplitude and cycles number. The forces that load the lever pin insignificantly increase in dynamic regime meaning that the stresses amplitude does not change.

Correlating this fatigue diagram with the data given in chapter 3 , the number of fatigue cycles can be found as follows:

- for operating in power adjustment regime result approximately 22 cycles/hour;

- for operating in primary adjustment regime result approximately 110 cycles/hour;

- for a combinative operating, normal regime and power adjustment regime, result approximately 9 cycles/hour.

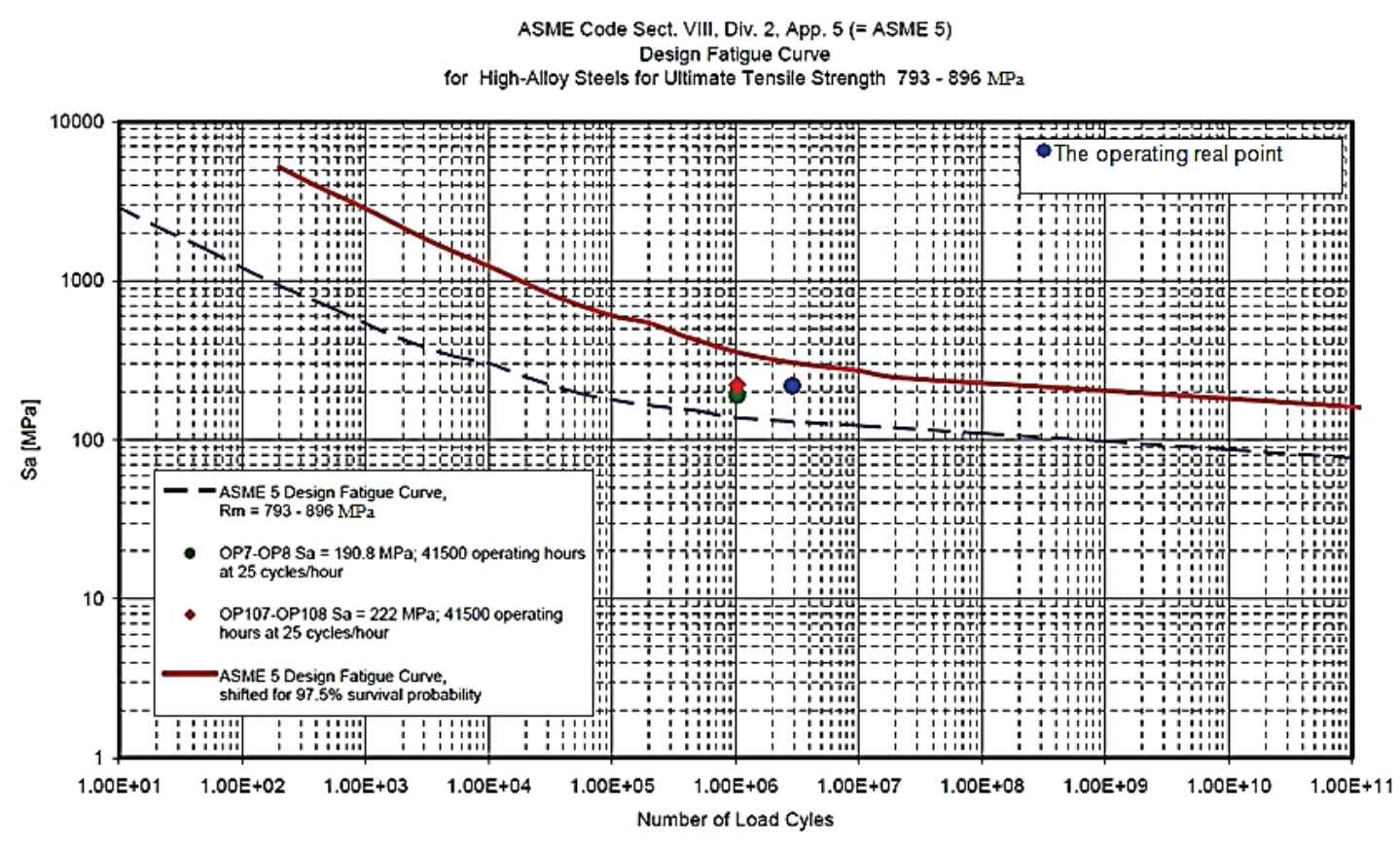

Figure 16 Fatigue diagram

If an operating time of 5 years is considered in mixed operating regime and 3 years in frequency adjustment 
regime, having insensibility by $\pm 10 \mathrm{mHz}$, for 7000 operating hours/year, the fatigue cycles number obtained is:

5 years $\times 7000 \mathrm{~h} \times 9$ cycles $/ \mathrm{h}+3$ years $\times 7000 \mathrm{~h} \times 110$ cycles $/ \mathrm{h}=$ $=315000+2310000=2625000$ cycles

\section{Conclusions}

From the entire analysis above, the following can be concluded:

- In order to estimate lifetime of the operating mechanism of the Kaplan turbine runner blades, a number of 9 cycles / hour was taken in consideration. This cycles' number was determined by measurement, in real operating conditions;

- the number of stress cycles was obtained by processing the measured data from a period of two years;

- from numerical simulation it can be observed that the maximum stress is located in the transition region between the pin and the lever body;

- maximum elongation is located at the end of the pin;

- for the unfavourable operation condition, from the finite element analysis, a force of $2852 \mathrm{kN}$ on pin resulted. This force was used for structural analyses;

- from operating tests a force of $2839,53 \mathrm{kN}$ results on maximum rotor actuator piston,. From dynamical analysis, the resulting force was of $2852 \mathrm{kN}$, a very low increase from the measured one. In that situation it can be concluded that, at lower speeds of rod (around $1 \mathrm{~mm} / \mathrm{s}$ ), the rod direction change does not produce increases of forces, stresses or stresses amplitude in lever pin;

- the statically structural analysis, for most unfavourable case, reveals a maximum value of equivalent von Mises stresses of $348 \mathrm{MPa}$. This value is registered on pin base. The maximum displacement is to the pin head, having a value of $0,48 \mathrm{~mm}$;

- for operating condition: $H=26,76 \mathrm{~m}$ and $P=192$ $\mathrm{MW}$, without a fatigue stress of lever pin material, the resulting stresses are in allowable limits, the piece having a safety factor of 1,78 , in pin area;

- the stress amplitude from lever pin is the one resulting from linear static calculus, being of approximately $200 \mathrm{MPa}$;

- the real point of operating is dangerously approached by the fatigue curve of $97,5 \%$.

- the calculus method presented in this paper offers good results, but needs a good knowing of operating condition.

- the main problem for this kind of calculus is to know the real number of fatigue cycles that, as is shown, strictly depends on operating condition.

\section{Acknowledgement}

The work has been funded by the Sectoral Operational Programme Human Resources Development 2007-2013 of the Ministry of European Funds through the Financial Agreement POSDRU/159/1.5/S/132395.

\section{References}

[1] Fajdiga, G. Computational fatigue analysis of contacting mechanical elements. // Technical Gazette. 22, 1(2015), pp. 169-175. https://doi.org/10.17559/TV-20140429122305

[2] Rusu, O., ş.a. Fatigue of Metals - Vol I. - Calculus bases // Ed. Technical, Bucuresti, Romania, 1992.

[3] Rusu, O. Strength of Materials - part III // Polytechnic Institute, Bucuresti, Romania, 1986.

[4] Miclosina, C. O.; Balint, D. I.; Campian, C. V.; Frunzaverde, D.; Ion, I. A method to combine hydrodynamics and constructive design in the optimization of the runner blades of Kaplan turbines. // 26th IAHR Symposium on Hydraulic Machinery and Systems IOP Publishing IOP Conf. Series: Earth and Environmental Science 15 (2012) 032015, China, 2012.

[5] Brekke, H. Performance and safety of hydraulic turbines // 25th IAHR Symposium on Hydraulic Machinery and Systems, IOP Conf. Series: Earth and Environmental Science / Timisoara, Romania. 12, (2010). https://doi.org/10.1088/1755-1315/12/1/012061

[6] Liu, X.; Luo, Y. Y.; Wang, Z. W. Fatigue Analysis of the Piston Rod in a Kaplan Turbine Based on Crack Propagation under Unsteady Hydraulic Loads. // 27th IAHR Symposium on Hydraulic Machinery and Systems (IAHR 2014), IOP Conf. Series: Earth and Environmental Science / Montreal, Canada. 22, (2014), 012017. https://doi.org/10.1088/1755-1315/22/1/012017

[7] Urquiza, G.; Garcia, J. C.; Gonzalez, J. G.; Castro, L.; Rodriguez, J. A.; Basurto-Pensado, M. A.; Mendoza, O. F. Failure analysis of a hydraulic Kaplan turbine shaft. // Engineering Failure Analysis - June 2014. https://doi.org/10.1016/j.engfailanal.2014.02.009

[8] Campian, C. V.; Frunzaverde, D.; Nedelcu, D.; Marginean, G. Failure analysis of a Kaplan turbine runner blade. // IAHR, 24th Symposium on Hydraulic Machinery and Systems, October 27-31, FOZ DO IGUASSU, Brazilia, 2014.

[9] Miclosină, C. O.; Campian, C. V.; Frunzaverde, D. Finite element analysis of an outer bearing bush of a Kaplan turbine. // Annals of DAAM for 2011 \& Proceedings of the 22nd International DAAAM Symposium "Intelligent Manufacturing \& Automation: Power of knowledge and creativity", 23-26th November 2011, Vienna, Austria, pp. 169-170.

[10] Campian, C. V. a.o. Technical Report CCHAPT nr. U-08400-262 // December 2008

[11] Larin, O. O.; Trubayev, O. I.; Vodka, O. O. The fatigue life-time propagation of the connection elements of longterm operated hydro turbines considering material degradation. // PNRPU Mechanics Bulletin, 1(2013), pp. 167-193. https://doi.org/10.15593/2224-9893/2014.1.09

[12] FKM-Guideline, Analytical strength assessment of components in Mechanical Engineering // Ed. Forschungskuratorium Maschinenbau Frankfurt / Main, ISBN 3-8163-0425-7, 2003.

[13] Fuji Electric, Calculation of Fatigue Life of Runner Blade Operating Mechanism // Appendix C-3.

[14] Huth, H. J. Fatigue Design of Hydraulic Turbine Runners. // $\mathrm{PhD}$ Thesis, Norwegian University of Science and Technology, Department of Engineering Design and Materials, Trondheim, Norway, February 2005.

[15] Andritz Hydro, Failure of Runner Lever 11A to Runner Blade 11A FEM and Fatigue Strength Investigations // Technical Report no Z/09 - 080, May, 2009. 


\section{Authors' addresses}

Dr. eng. Ana-Maria Budai, Lecturer

"Eftimie Murgu" University of Resita

Piata Traian Vuia, nr. 1-4, 320085, Resita, Romania

am.budai@uem.ro

Dr. eng. Viorel Campian, Full Professor

"Eftimie Murgu" University of Resita

Piata Traian Vuia, nr. 1-4, 320085, Resita, Romania

v.campian@uem.ro

Dr. eng. Doina Frunzaverde, Full Professor

"Eftimie Murgu" University of Resita

Piata Traian Vuia, nr. 1-4, 320085, Resita

d.frunzaverde@uem.ro

Dr. eng. Calin Miclosina, Associate Professor

"Eftimie Murgu" University of Resita

Piata Traian Vuia, nr. 1-4, 320085, Resita, Romania c.miclosina@uem.ro

Eng. Damaschin Pepa, PhD, Student

"Eftimie Murgu" University of Resita

Piata Traian Vuia, nr. 1-4, 320085, Resita, Romania dpepa@ucmr.ro 